\title{
Enhancing skills development and reflective practise in students during their programme of study
}

\author{
Janis MacCallum \& Samantha Campbell Casey* \\ Edinburgh Napier University
}

*Corresponding Author: sa.campbell@napier.ac.uk

Keywords: Employability skills, flexibility, reflective practice, competency frameworks, professional planning

\begin{abstract}
The transition to the workplace can be challenging for new graduates. At Edinburgh Napier our approach is to work proactively with students to prepare them for the world of work. Staff within the School of Applied Sciences have partnered with both internal and external stakeholders to provide opportunities for students to gain experience and develop skills to support this transition. This led to the development of the Skills Passport project within the School and a strong focus on graduate employability. At the core of this is a Skills Evidence and Evaluation Record (SEER), modelled upon employer competency frameworks, and aiming to help students understand the professional development required by industry, assess gaps in their personal skills, and proactively engage with opportunities in order to tailor a plan for their own professional development needs. There are a number of key challenges with this approach: firstly, getting students to engage with these opportunities (see their value as integral to their personal development); secondly, ensuring a joined up approach (building links from year to year and across modules); and lastly, ensuring staff buy-in. Continued and appropriate support is required to ensure we can effectively support these issues and we encourage all stakeholders including staff, students and employers to reflect on the effectiveness of this approach. Here we present some data and reflections on how our approach has worked and where it needs further refinement into a flexible tool that
\end{abstract}

will stand the test of time, continue to support students effectively and also meet the changing needs of industry.

\section{Introduction}

The Life Sciences industry is an important part of the UK economy and is key for economic growth. The Scottish Life Sciences Strategy aims to double the size of the sector in Scotland by 2025 , requiring a highly skilled and motivated workforce (Gunn and Kaufmann, 2011; Life Sciences Scotland, 2017). Life Sciences graduates produced by universities will form the basis of this workforce, thus universities need to equip graduates with the skills required to service the needs of the sector and provide an interesting and stimulating course (Yorke et al., 2006). A survey of Life Sciences employers identified problematic gaps in graduate recruits around skills and work related-experience, reporting that core skills such as problem solving, team working, planning and organization were lacking (Life Sciences Scotland, 2011), which is in line with other research (Maxwell et al., 2009, Artess et al., 2016). As a result, staff in the School of Applied Sciences at Edinburgh Napier University (ENU), in partnership with staff from Employability and Opportunities, developed the Skills Passport to help students develop and reflect upon their employability skills. We have engaged a range of local Life Sciences employers to join an Employer Liaison Panel (ELP) to help inform the project about the current challenges in the sector and advise on the ongoing work to embed the Skills 
Passport across our programmes (Maxwell et al., 2009). This has been critical in identifying more detail around skills gaps and how this is tackled from an industry perspective, as well as providing support for a number of our careers and employability related activities (Cai et al., 2012; Jackson, 2015). The project builds upon research outlining the effectiveness of reflection in enhancing students' practical skills in bioscience (Parry et al., 2012; Speake et al., 2007), since reflection is already well known to contribute to the learning cycle (Kolb, 1984), and is a skill requiring practice to develop and aid the transition to deeper learning and personal literacy (McClure, 2005; Rust, 2016).

At the core of our approach is the studentowned Skills Evidence and Evaluation Record (SEER) (Fig.1), to help students understand the skills required by industry and identify gaps in their personal skills. Self-reflection and action planning for skills development is encouraged at all stages by integrating reflective segments into assessments and through engagement with their personal development tutor (PDT) to review progress against this framework (Pegg et al., 2012; AbuAl-Aish and Love, 2013; Nagaranjan and Edwards, 2015, Greenbank, 2015; Leinonen et al., 2016) . Through ongoing reflection and action planning, along with exposure to employability opportunities (networking events, site visits etc.) and non-academic activities (Lau et al., 2014) students can discuss aspects of their skills development, articulate these, and learn about expectations and demands from industry staff, and thus be better prepared to succeed in graduate recruitment processes (Villa and Albertin, 2010; Jarvis et al., 2012). Each skill (including generic skills) within the SEER are clearly defined and have an associated set of competencies to allow students to assess their development in key areas (e.g. problem solving, time management, and specific scientific skills such as pipetting and spectroscopy) using a STAR$L$ format (Fig.2), a modified version of STAR (The Guardian, 2014, Stewart et al., 2016). Students are introduced to the Skills Passport and the SEER document at the start of year 1 , and encouraged to engage and record their skills development, personal reflections and personalise their document to take account of their career aspirations and their individual style of working. Each year we undertake an evaluation to determine the level of uptake, ease of use and identify if further refinements need to be made. Here we report on some key points from this evaluation and the challenges faced by the team in implementing an employability based approach within a programme of study.

\section{Methods}

Yearly evaluation of undergraduate Biological Sciences programme students and staff on their experience of the Skills Passport is done in a variety of ways, including online questionnaires (NoviSurvey) and face to face Tuningpoint voting systems in the classroom. We have maintained consistency in the questions used each year to ensure we can effectively evaluate changes between year groups and as students progress through their programme of study. Questions relating to knowledge of the tool, how the tool is being used and more importantly how this tool is viewed in terms of skills development are included. Demographic data is collected to determine any effects on the results obtained. Students have the opportunity to provide open ended comments during the evaluation process and staff have found these invaluable in making adjustments and improvements.

\section{Results and Discussion}

\section{Awareness and Engagement}

Work around skills development and employability is undertaken at all levels to engage students in the Skills Passport process as early as possible to improve motivation and effectiveness (Fig.3) (Gold et al., 2010). The Skills Passport has been provided in a variety of formats and students are encouraged to personalise it. Feedback on how the format of the tool influences usage suggests students are engaging in a variety of ways, but the accessibility and ease of use are of paramount importance. 
Demonstrating initiative

\begin{tabular}{|c|c|c|}
\hline Negative & Positive & Exemplary \\
\hline $\begin{array}{l}\text { - Requires regular } \\
\text { reminders to } \\
\text { complete work } \\
\text { assignments. } \\
\text { - Requires regular } \\
\text { reminders for } \\
\text { instructions of how } \\
\text { to perform tasks. } \\
\text { - Demonstrates lack } \\
\text { of confidence and } \\
\text { ability to deal with } \\
\text { challenges and } \\
\text { obstacles. } \\
\text { Often relies on } \\
\text { assistance to work } \\
\text { through issues } \\
\text { - Requests help } \\
\text { before trying to get } \\
\text { an understanding } \\
\text { of unfamiliar tasks } \\
\text { for self. } \\
\text { - Proceeds on } \\
\text { initiatives even } \\
\text { when told they are } \\
\text { ineffective or when } \\
\text { directed not to. }\end{array}$ & $\begin{array}{l}\text { - Demonstrates a } \\
\text { positive attitude } \\
\text { towards getting } \\
\text { things done } \\
\text { - Able to work } \\
\text { without detailed } \\
\text { direction } \\
\text { - Tries to understand } \\
\text { unfamiliar tasks } \\
\text { before asking for } \\
\text { help } \\
\text { - Digs beneath the } \\
\text { obvious to get at } \\
\text { facts } \\
\text { - Anticipates } \\
\text { potential problems } \\
\text { and takes } \\
\text { appropriate action }\end{array}$ & $\begin{array}{l}\text { - Goes beyond } \\
\text { expectations } \\
\text { without being } \\
\text { asked } \\
\text { - Seeks out and/or } \\
\text { accept additional } \\
\text { responsibilities } \\
\text { - Creates } \\
\text { opportunities or } \\
\text { minimises potential } \\
\text { problems by } \\
\text { anticipating and } \\
\text { preparing for these } \\
\text { in advance }\end{array}$ \\
\hline
\end{tabular}

Example competency questions to assess initiative:

- Describe a project or assignment that you were given that you found challenging. How did you approach it?

- Give an example of a time when you took initiative to make something happen that otherwise would not have been done.

- Give an example of a time when you have gone beyond what was expected of you.

Figure 1 Extract taken from the SEER document.

\section{STARL format}

$$
\begin{aligned}
& \text { STAR stands for: } \\
& S=\text { Situation } \\
& T=\text { Task } \\
& A=\text { Action } \\
& R=\text { Result } \\
& L=\text { Learning }
\end{aligned}
$$

There are other acceptable ways to format answers to competency questions but all are similar. Examples include: SCAR (Situation, Challenge, Action, Result); CAR (Context, Action, Result); EAR (Example, Action, Result).

Figure 2 The STARL concept 


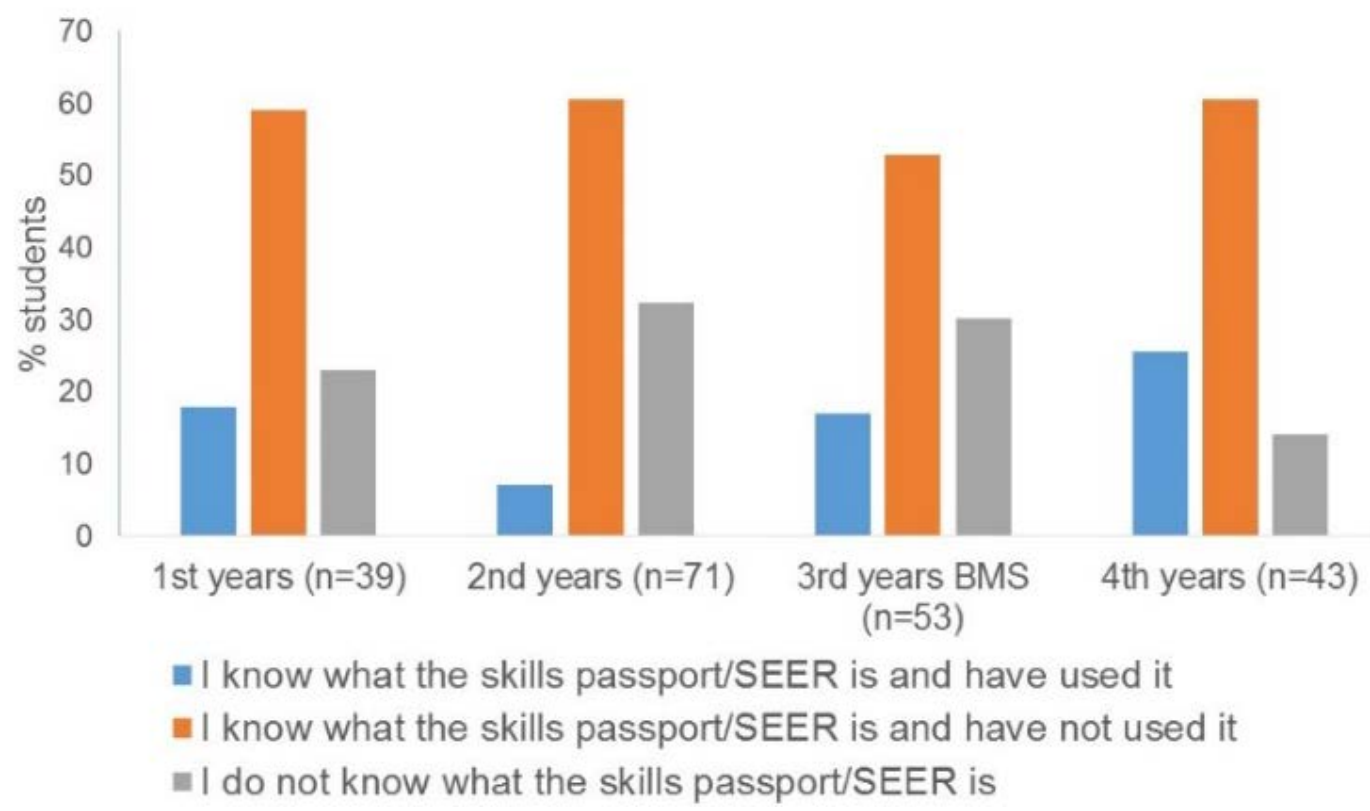

Figure 3 Data shown is from the 2016-17 evaluation. General awareness of the Skills Passport is variable across the years, and does not seem to follow clear cut patterns. There is a fairly consistent number of students (50-60\%) with an awareness of the Skills Passport who have not used it (orange bars); grey bars highlight students who are not aware of the passport (10-30\%) even by the end of 4 years. This leaves only a small percentage of students who have an awareness and actually use it in some way to support their transition into the workplace $\left(5 \%\right.$ in $2^{\text {nd }}$ year rising to nearly $30 \%$ in $4^{\text {th }}$ year).

\section{"I have found very useful how it summarises all of the skills and is easy \\ to evaluate which ones I have developed".}

At present many students use a Word-based version for reasons of flexibility and portability, but we are in the process of creating an App version that will allow students to engage using their personal mobile devices via a Campus $M$ interface, and this may also aid staff in linking classroom activities and skills development to the appropriate skill in the Passport (Abu-AlAish and Love, 2013; Gikas and Grant, 2013; Kori et al., 2014; Leinonen et al., 2016). However, we need to be realistic about the demands placed on students and how much they are able to engage with activities outside their programme (Villar and Albertin, 2010). We can encourage engagement, and target relevant and purposeful experiences that complement their studies, but students will take part to varying degrees or not at all (Tomlinson, 2012), so our focus must continue to be in helping them to see the value as key to their professional development and enhancing their employability potential (Tymon et al., 2017).

\section{A Joined-up approach}

Comparing student responses over the last three years for the same year groups (Fig.4.), there is no consistent picture, until we reach the $3^{\text {rd }}$ and $4^{\text {th }}$ year students. In particular, there are now fewer students who are not using the passport and therefore there has been a growing awareness of the importance of their skills development, which is very positive. There is also a general upward trend highlighting that we are building an increased awareness of the passport each year.

What is also clear is that there has been a loss of momentum over the period from 14/15 through to this year in terms of increasing the use of the skills passport, especially with the year 1 and 2 students) and to some extent with the year 3 students (in line with other research - see Rae, 2007; Tymon, 2017). During this period we lost a number of key individuals who were closely involved with the inception of this 
project leaving a much smaller team and necessitating changes in how we engage with the student cohorts (Pegg et al., 2012; Jackson, 2012; Greenbank, 2014). Additionally, data may be skewed by direct entry students, since we have variable numbers of these students joining in years 2 and 3.

We have also undertaken cohort analysis for this year's final year students, to see how their attitudes have changed over the period 2014/15-2016/17 (Fig. 5). We have peak usage of the passport in year 3 , a point at which there is a strong focus on careers aspects and engaging with employers through networking events, site visits etc. This then dips in year 4, perhaps due to workload constraints and the fact that students are very much focused on their degree, and the classification that they are working towards, rather than considering the next stages (Tomlinson, 2008; Brainine, 2008; Tymon, 2015).

Ultimately, we have fewer students going out into the world of work who are unaware of the importance of skills attributes; $85 \%$ of our students at least have an awareness or have actively worked on skills development.

Implementing a skills approach which is joined up, building linkages both horizontally and vertically through our programmes, and changes for internal revalidation and external accreditation by the Royal Society of Biology have highlighted that the mapping of skills to outcomes needs to be flexible to allow for change and evolution of courses. The changing needs of employers also need to be considered and engaging with employers via our ELP (Wilton, 2014), and also by undertaking evaluation with our students and staff, generates regular feedback that can be used to make changes and updates to improve the format and increase use of the tool. Students from $3^{\text {rd }}$ and $4^{\text {th }}$ years are more likely to take up employability opportunities and use the Skills Passport as there are clear links to their future transition into the workplace. However considerable numbers still do not engage with these opportunities. The embedding of these approaches within the programme, and engagement within the ELP themselves, is therefore important in making it difficult to avoid opportunities for skills improvement, and linking these to what the students are doing is also key to success (Tymon, 2015).

\section{Staff Buy-in (Support for Employability activities in a changing workplace)}

Getting staff on board to help provide backup through the PDT system and make sure that students engage with the skills passport, we need the staff to be clear of what the passport does, and how it can help our students (UKCES, 2008; Pegg et al., 2012). Feedback from staff suggests variation in their knowledge of the tool and how they use it with students. Staff involved in teaching the more practical based elements of the programme are able to articulate the links between the skills that students are learning in the laboratory and the Skills Passport, and have a role in assessing students' skills development against a range of competency matrices during classes. Other staff, including personal development tutors, feel that they would benefit from additional guidance on how to use this tool effectively with their students.

"I don't know how others are using it, how it applies to my teaching and don't have much time"

\section{"No information on how to implement or how to advise students on its use and value"}

A number of students also report a lack of confidence in using this tool. Therefore it is essential we provide additional guidance and support sessions to improve their use of this tool and increase engagement. Whilst the project team have worked hard to articulate key benefits and provide support to students and staff, clearly there is more work to do in this area.

\footnotetext{
"Need to raise awareness and buy-in from staff - perhaps this needs wider input on design and application from staff. Promotion and information for academics needs to be more accessible."
} 
Enhancing skills development and reflective practise in students during their programme of study
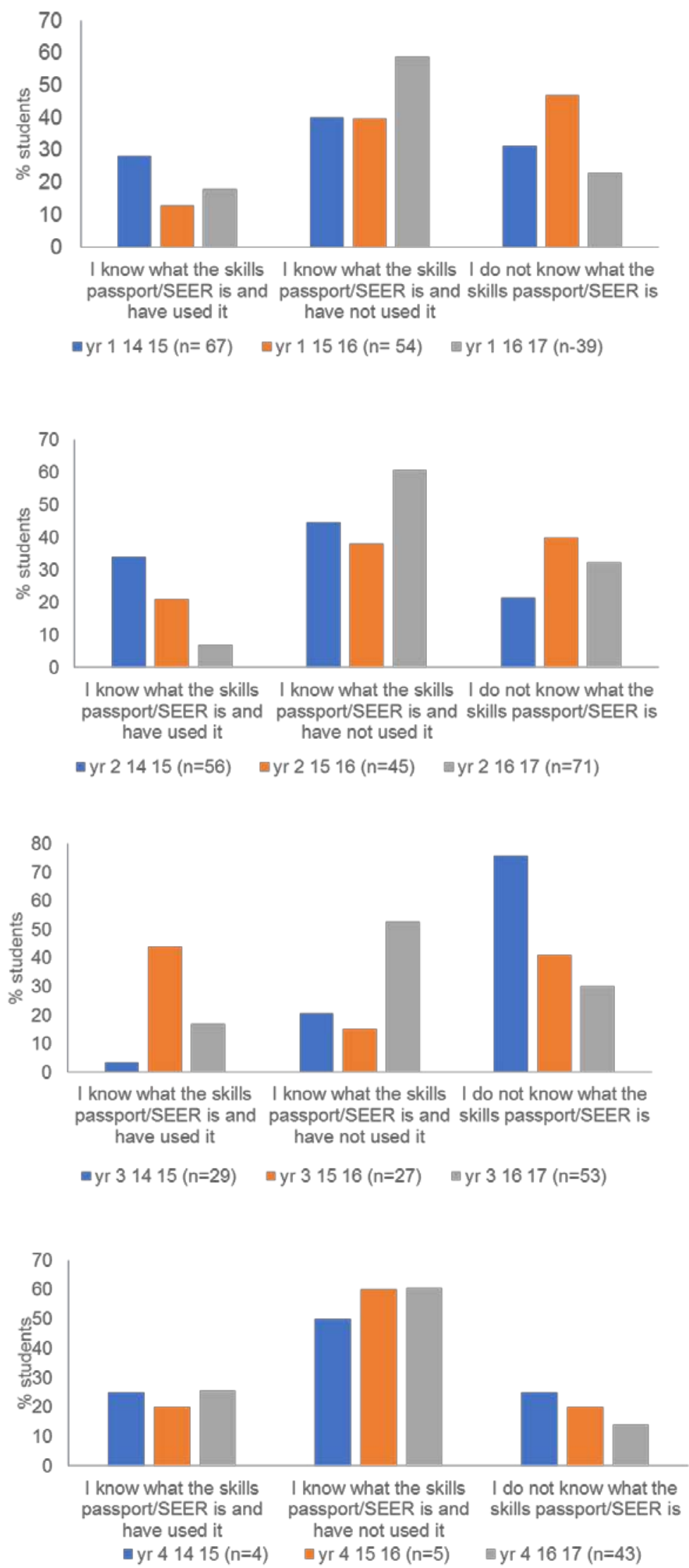

Figure 4 Year Group Analysis Data gathered from 14/15 through to 16/17 looking at how student responses compare in each year of study. 


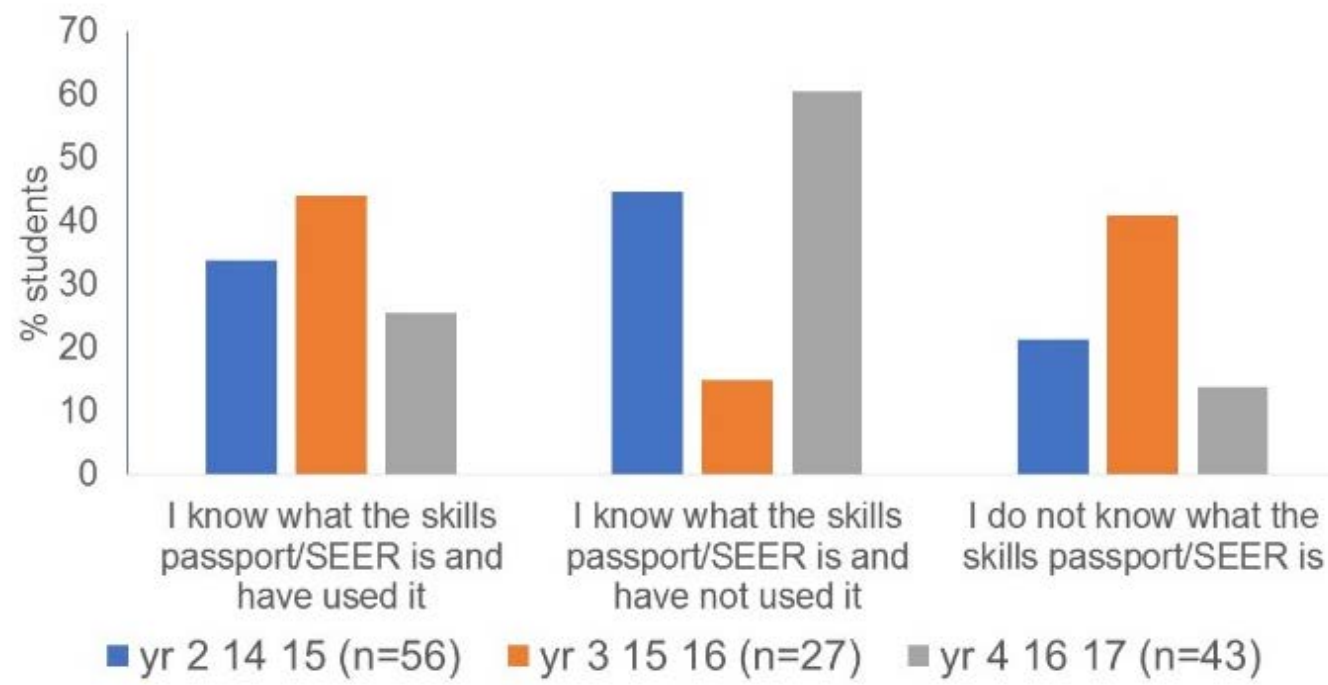

Figure 5 Analysis of a single cohort of students as they move from year 2 through to the final year of their programme in 2016/17. This indicates that knowledge and use of the Skills Passport varies between years even within the same cohort. ( $2^{\text {nd }}$ year $n=56$; $3^{\text {rd }}$ year $n=27 ; 4^{\text {th }}$ year $n=43$ )

More positively, a number of students who have actively engaged with this tool have secured employment by using the Skills Passport to help them to articulate their skills at interviews and in job applications, and using these students as potential case studies or exemplars may encourage students to see the value of engaging with the Skills Passport for their future benefit. For this reason a number of student and staff voices have been recorded to provide some positive role models for our students, and these are shared via our VLE site for the Skills Passport.

\section{Conclusions}

Progress in implementing the Skills Passport has been slower than we would have originally anticipated. Although overall engagement and awareness have increased we would like this to be higher and this is a key focus of our future work. There are a number of potential barriers that we need to overcome including increased competition for student time, especially in the later years of the programme, and we need to consider how we can structure activities to make them more effective. Students also do not fully understand what employers want or need and therefore we are embedding targeted activities in year 1 and 2 around the language of job adverts and linking this to the skills students will learn during their course in order to build employability confidence in our students. Helping students to gain confidence in their skills and how to articulate them is an important employability skill and was always the key focus of the original project. Ensuring that we contextualize activities and link skills within and across the programme is clearly important so that students will be more likely to take up opportunities to gain appropriate experience and enhance their skills. The redevelopment of the new programme, and its alignment to the Royal Society of Biology framework, has helped to highlight to staff the importance of these skills and the need for them to support students with their skills development. With the roll out of our new programme this year and other targeted activities, including the development of a mobile App, in continuing our evaluation we hope to see a measured improvement in engagement over the next few years.

\section{References}

Abu-Al-Aish, A., \& Love, S. (2013). Factors influencing students' acceptance of $M$ learning: An investigation in Higher Education. The International Review of Research in Open and Distributed Learning, 14(5) retrieved 23rd June, 2017 from:

DOI: 10.19173/irrodl.v14i5.1631. 
Artess, J., Hooley, T., \& Mellors-Bourne, R. (2016). Employability: A review of the literature 2012-16. (A report for the Higher Education Academy) Retrieved 25th June, 2017 from https://www.heacademy.ac.uk/system/files/res ources/employability_a_review_of_the_literatu re.pdf

Branine, M. (2008). Graduate recruitment and selection in the UK. A study of recent changes in methods and expectations. Career Development International. 13(6), 497-513. DOI: 10.1108/13620430810901660

Cai, Y. (2012). Graduate employability: a conceptual framework for understanding employers' perceptions. Higher Education. 65(4), 457-469.

DOI: $10.1007 /$ s10734-012-9556-X

Gikas, J., \& Grant, M.M. (2013). Mobile computing devices in Higher education: Student perspective on learning with cellphones, smartphones \& social media. Internet and Higher Education, 19, 18-26.

DOI: 10.1016/j.iheduc.2013.06.002

Gold, J., Holden, R., Iles, P., Stewart, J. \& Beardwell, J. (2010). Human resource Theory Development: Theory and practice. Basingstoke: Palgrave Macmillan.

Greenbank, P. (2014). Career decisionmaking: "I don't think twice, but it'll be alright". Research in Post-compulsory Education, 19(2), 177-193.

DOI: $10.1080 / 13596748.2014 .897507$

Greenbank, P. (2015). Still focusing on the "essential 2:1": Exploring student attitudes to extra-curricular activities. Education and Training, 57(2), 184-203.

DOI: 10.1108/ET-06-2013-0087

Gunn, V. \& Kaufmann, K. (2011). Employability and the austerity decade. Graduates for the 21st Century: Integrating the Enhancement themes. Glasgow: QAA Scotland, p.6. Retrieved 20th June 2017 from http://www.enhancementthemes.ac.uk/docs/p ublications/employability-and-the-austeritydecade.pdf
Jackson, D. (2012). Business undergraduates' perceptions of their capabilities in employability skills: implications for industry and higher education. Industry and Higher Education. 26(5), 345-356.

DOI: 10.5367/ihe.2012.0117

Jackson, D. (2015) Employability skill development in work-integrated learning: Barriers and best practice. Studies in Higher Education. 40(2), 350-367.

DOI: $10.1080 / 03075079.2013 .842221$

Jarvis, J. Dickerson, C., \& Stockwell, L. (2012). Staff-student partnership in practice in higher education: The impact on learning and teaching. Procedia - Social and Behavioral Sciences, 90(Oct.), 220-225.

DOI: 10.1016/j.sbspro.2013.07.085

Kolb, D.A. (1984). Experiential Learning: Experience as the source of learning and development. New Jersey: Prentice Hall.

Kori, K., Pedaste, M., Leijen, A., \& Maeots, M. (2014). Supporting reflection in technologyenhanced learning. Educational Research Review, 11, 45-55.

DOI: 10.1016/j.edurev.2013.11.003

Lau, H.H., Hsu, H.Y., Acosta, S., \& Hsu, T.L. (2014). Impact of participation in extracurricular activities during college on graduate employability: an empirical study of graduates of Taiwanese business schools. Educational Studies, 40(1), 26-47.

DOI: 10.1080/03055698.2013.830244

Leinonen, T., Keune, A., Veermans, M., \& Toikkanen, T. (2016) Mobile Apps for reflection in learning: A design research in $\mathrm{K}-12$ education. British Journal of Educational Technology, 47(1), 184-202. DOI:10.1111/bjet.12224.

Life Sciences Scotland (2011). Scottish Life Sciences Employer Skills Survey 2010. Retrieved 25 November, 2016 from http://www.lifesciencescotland.com/connectio ns/news/news-content/scottish-life-sciencesemployer-skills-survey-2010.aspx

Life Sciences in Scotland, (2017), Life Sciences for Scotland 2025 Vision: 
Enhancing skills development and reflective practise in students during their programme of study

Accelerating Growth, Driving Innovation. Retrieved 17th June 2017 from: http://www.lifesciencesscotland.com/pdf/Life\% 20Sciences\%20Strategy\%20for\%20Scotland \%202025\%20Vision.pdf

Maxwell, G., Scott, B., Macfarlane, D., \& Williamson, E. (2009). Employers as stakeholders in postgraduate employability skills development. International Journal of Management Education. 8(2), 13-22.

DOI:10.3794/ijme.82.267

McLure, P. (2005). Reflection on Practice. Retrieved 20 January, 2017 from http://cw.routledge.com/textbooks/978041553 7902/data/learning/8_Reflection\%20in\%20Pra ctice.pdf

Nagaranjan, S. \& Edwards, J. (2015) The role of Universities, employers, graduates and professional associations in the development of professional skills of new graduates. Journal of Perspectives in Applied Academic Practice. 3(2), 26-37

DOI: 10.14297/jpaap.v3i2.137

Parry, D., Walsh, C., Larsen, C. \& Hogan, J. (2012). Reflective Practice: a place in enhancing learning in the undergraduate bioscience teaching laboratory. Bioscience Education, 19, 35-44.

DOI: 10.11120/beej.2012.19000004

Pegg, A., Walcock, J., Hendy-Isaac, S., \& and Lawtron, R. (2012). Pedagogy for Employability. York, UK: Higher Education Academy

Rae, D. (2007). Connecting enterprise and graduate employability. Challenges to the Higher Education culture and curriculum? Education + Training, 49(8/9), 605-619.

DOI: $10.1108 / 00400910710834049$

Rust, C. (2016). Shifting the focus from skills to "graduateness". Phoenix, 148, 8-10.

Speake, T., Fostier, M. \& Henery, M. (2007). The use of reflective practice to support a final year team research project in biosciences. Proceedings of the Science Learning and Teaching Conference 2007.
Stewart, J., Shanmugam, S. \& Seenam, C. (2016). Developing 21st century graduate attributes: incorporating novel teaching strategies in a physiotherapy curriculum. European Journal of Physiotherapy. 18(3), 194-200.

DOI: 10.1080/21679169.2016.1181205

The Guardian (2014) Using the Star technique to shine at job interviews: a how-to guide. Retrieved 31 January, 2017 from http://www.theguardian.com/careers/careersblog/star-technique-competency-basedinterview

Tomlinson, M. (2008). "The degree is not enough": Students perceptions of the role of higher education credentials for graduate work and employability. British Journal of Sociology of Education. 29(1), 49-61.

DOI: 10.1080/01425690701737457

Tomlinson, M. (2012). Graduate employability: A review of conceptual and empirical themes. Higher Education Policy, 25(4), 407-431. DOI: $10.1057 /$ hep.2011.26

Tymon, A. (2017). The student perspective on employability. Studies in Higher Education. 38(6), 841-856.

DOI:10.1080/03075079.2011.604408.

UKCES, (2008). UK Commission for Employment and Skills - Employability Skills Project. Review of evidence on best practice in teaching and assessing employability skills. Retrieved 3rd May 2017 from: http://webarchive.nationalarchives.gov.uk/201 40108132755/http://www.ukces.org.uk/assets/ ukces/docs/publications/employability-skillsproject.pdf

Villar, E. \& Albertin, P. (2010). "It is who knows you". The positions of university students regarding international investments in social capital. Studies in Higher Education, 35(2), 137-154.

DOI: $10.1080 / 03075070902957080$

Wilton, N. (2014). Employability is in the eye of the beholder: Employer decision-making in the recruitment of placement students. Higher Education, Skills and Work-based Learning, 4(3), 242-255. 
Enhancing skills development and reflective practise in students during their programme of study

DOI: 10.1108/HESWBL-07-2014-0027

Yorke, M. (2006) Employability in higher education: what it is - what it is not. York: Higher Education Academy. Retrieved 31
January, 2017

from

http://www.employability.ed.ac.uk/documents/ Staff/HEA-Employability_in_HE(Is,IsNot).pdf 